\title{
The Relevance of Procurement in Public Administration: A South African Perspective
}

\author{
Gezani Mazibuko \\ First Choice Achievers Learning Centre NPO, South Africa (ZA) \\ hlohlo@lantic.net, gezanimazibuko@gmail.com
}

\begin{abstract}
Public procurement is a big industry in public administration as taxpayers' money spent by the government on goods, services and infrastructure accounts for the massive gross domestic product (GDP) of a country. This study upholds the idea that public procurement is relevant and activity of public administration. The public administration atmospheres focus on macro milieus and support the government to advance consciousness, dynamics convoluted purchases of government goods, services, works and infrastructure development. Such external environmental aspects moving public and private buyers in the same direction are that of reconnoitring those critical environmental inspirational procurement procedures. This calls for public administrators to design bid processes according to the above-mentioned influences, as they are cradles of government financial spending and economic progression. Public administration philosophies succor to offer dimensions and theoretical conceptual work on how procurement should proceed within the government. Such public administration theories are paramount to transcend the understanding of procurement in the public sector. Specifically, the generic administrative functions as they relate to public procurement are relevant in expounding this research. The paper is the exploratory one, seeking to expand the knowledge base and stimulate discourse on procurement practices in government. A qualitative research and content analysis was employed in this study. It can be deduced that there is the relevance of procurement in government, as government procures and spends billions and even trillions of rands financing goods, services, public works, massive infrastructure development-highways, bridges, dams, airports, seaports and other essential amenities. These massive kinds of procurement have to be accounted for against corrupt and state capture activities.
\end{abstract}

Keywords: Public, Procurement, Administration, Procedures, Environments

\section{Introduction}

Procurement as a main portion of the government budget and expenditure needs to demonstrate government efficiency in purchasing (OECD, 2009). It must be stated beforehand that procurement is a grouping together of philosophy and activity exercise (Lamidi, 2015). Government procurement as a subfield impacts private sector offerings and is an authoritative instrument that stimulates public spending intentions in states and theories pertaining to that need to be understood. The study of procurement as a subfield of public administration is principal for understanding what public administration is and the relevance of procurement to that effect. Rutgers (2010), articulates the object of study of Public Administration which will also help to venture into the discourse of procurement in governments.

Procurement as a subfield, an activity of Public administration can be considered a base and ladder towards the advancement of -administration. Procurement is one of the activities in public administration within the public finance and public expenditure paradigm. Public procurement as a program of government dealing with bid procedures regarding demand planning, bid stipulations, assessment, award, contract performance is significant to government expenditure management (Mazibuko, 2018). Certainly, public administration enhances development, transformation and skills and governance, equity while procuring goods, services and infrastructure. Accountability is the cornerstone for public procurement and financial management (Mazibuko \& Fourie, 2013) in general. The ideologies in public administration guide how procurement training and management and the principles are put into practice in government. The study, therefore, sought to expand the knowledge base and stimulate discourse in the development of procurement as a practice and activity. 


\section{Conceptualisation framework}

In understanding procurement, it would be essential to figure out what public administration is and how it is practiced in society. Arguably, public administration is constitutional management that maneuvers in administration. It is machinery for executing administration programs. It is directed at studying how a nation's government is structured and functions (Lamidi, 2015). Public procurement deals with the acquisition by administrations and state-owned enterprises of physical infrastructure, roads, works, and infrastructure development (Fourie and Malan, 2020) There are various processes involved such as needs assessment, requisitioning, review, solicitation, evaluation and contract management, order management, invoicing approvals, record keeping and performance controls which warrant tight oversight.

Categorically, putting the procurement study in perspective, it must be considered a sub-field of public administration. Certainly, of all government activities, procurement is the most vulnerable to fraud and corruption. Nowadays, National Treasury and the Auditor General are worried about procurement practices and the scourge of corruption pandemic that throttles infrastructure development. The two institutions are public institutions operating within government administration. Public procurement is recognized as a public administration subfield (South Africa, Republic, 1996).The Constitution guides organs of states on how to contract for goods or services on procurement which is relevant to the system fairness, equity, efficiency and transparency. The administrative activities or functions are paramount in procurement. The importance of financing, organizing, procedures, controlling and management functions are advocated by scholars of notes in public administration (Ijeoma, 2013; Thornhill \& Van Dijk, 2010; Denhardt, Denhardt and Blanc, 2014; Fox, et al, 2004). The administrative functions activism cited by various scholars links with procurement practices, in government set up.

As stated above, public procurement is a subfield and activity of public administration (Raadschelders, 2011; Denhardt et al, 2014) and as such is fundamental to be studied as a separate course or qualification of Public Administration. Further, Public administration as an activity that relates to public procurement as a subfield cannot be overemphasized. Henry (2013) asserts that Public Administration has developed as an academic and professional field through a succession of various phases in its historic development. This stands to reason that procurement as a field of study can be replicated along with such phases if that cannot happen in one phase. History cannot be erased, it is imperative to state that goods and services were procurement in the past, as long as public administration was practiced, and public finances were organized at that time especially during the pre-history stage (Schumpeter, 1954). It should be noted, however, that, the activity deals with state institutions (Van der Waldt \& Du Toit, 1999) that procure goods and services and as such cannot be overemphasized. The procurement planning and needs assessment while procuring goods is a precursor for effective procurement in public administration (Shafritz, 2000). Frederickson, et al (2012) states that before public policy and public administration issues are understood, certain dependability of appreciation will be helpful. Some of the things to comprehend are issues and order of facts. Our understanding derived, will escort policy and accomplishments. To this end, the authority or efficacy of any theory hinges on its capability to pronounce, expound, and forecast issues beforehand. For a theory, to be useful, it should precisely label or represent a real-world occurrence.

Theories are critical in providing a stable focus of understanding what is experienced in public procurement and administration at large. In public procurement issues of oversight, procedures, methods and administrative functions should be predictable and depict the real-life situation. A theory delivers weight on a problem, empowers scholars to interconnect powerfully and afford a ladder to move to multifaceted relationships (Lamidi, 2015) with other actors. Above all, a theory challenges scholars to keep learning about government and the world in general. Elkatawneh (2019) posits that there are interactions between the administrative theory and policy-making on the division of work, organizing the procedures, hierarchy, authority, responsibility and control. Such matters are the building blocks for procurement practice in administration.

Theories of public administration are fundamental for the commencement of procurement understanding and development. It can be deduced that theories can provide logical structures for explaining and predicting individual and social phenomena (Thornhill \& Van Dijk, 2010; Flynn \& Davis, 2014; Basheka, 2012) and 
incidents of procurement corruption. Public administration is a combination of theory and practice which can be used in procurement (Rutgers, 2010). Procurement practice globally is fundamental in creating dependencies with the subfield such as public procurement. There are various international organizations (World Trade Organisation (WTO), which are at the forefront in articulating procurement legislation, procurement practices, appropriate systems of public procurement and anti-corruption strategies in public procurement (Uromi, 2014; WTO, 2012; 2011). The international instruments are essential for public administration worldwide as they crystallize benchmarks against and learn from the outstanding practices.

Theories are important in public administration and procurement in general. Theories are systematic apparatuses for appreciative, clarifying, given matters such as procurement. There are theories in various fields of study, public administration procurement included. The importance of theories is relevant to the administration of public procurement practice, namely: conflict of interests in organizations; governance; effectiveness; efficiency; professionalism and cannot be neglected. Consider the issues of leadership and improvement of administrative practices such as planning, organizing, staffing, directing, coordinating, reporting and budgeting. The theories show that the tenure of personnel; rules and regulations, competence, records management, and good governance are paramount for stability, improvement and the focus on public procurement as a policy tool (Mazibuko, 2018). The theories related to performance-based regarding the implementation of legislation and institutional arrangements of the procurement environment, amongst others.

Public administration machinery and its integral processes through which government performs its functions are governed by set rules and principles. In applying the rules, procurement organizations perform a vital and diverse role in delivering government services. State procurement functions are under mounting pressure to deliver results in a complex environment (Van der Waldt \& Du Toit, 1999; Fourie, 2015). Public administration principles focus attention on procedures to enhance transparency, good management, prevention of misconduct, accountability and control in procurement (OECD, 2009). Integrity cannot be overemphasized in government as government officials have to use funds, resources, assets and authority in terms of the intended official purposes. The principles of public administration are essential for a subfield such as public procurement, where major government spending takes place (Dobie \& Xinwa, 2015; Aziz, et al 2015).

Professional ethics, efficiency and effectiveness in the use of resource allocation through public procurement are supreme. The government spends billions of rands annually on goods, services, works and infrastructure development needed to deliver public services (Mazibuko \& Fourie, 2017). To guide procurement procedures, there are basic principles that are applied to public procurement administration. For example, accountability, value for money, competition, transparency, and equity (Aziz et al., 2015). Mazibuko \& Fourie (2017) posit that an effective procurement system that shows transparency, accountability is the way to go in public procurement( Holzer and Schwester, 2011; Schapper, 2008, Arrowsmith \& Quinot, 2013; Fourie, 2015; Graells, 2016, Garcia, 2009; Sobe, et al, 2011; Krivinsh \& Vilks, 2013). Transparency is the prohibition of discrimination, promotion of equality, transparency, and relativity (Schiavo-Campo \& McFerson, 2014).

In discussing procurement is critical to zoom in and articulate a bit about the public sector. The public sector is the key machinery of the state where public procurement takes its course. Procurement influences both domestic and international trade, given that governments spend approximately 10 to 15 percent of their GDP in the procurement marketplace. Public procurement budgets in South Africa amounts to 29 percent of GDP (Turley \& Perera, 2014) as it contributes enormously towards economic growth. Governments spend public monies to secure inputs and resources to achieve their objectives and create a significant impact on key stakeholders and wider society (South Africa, Republic, 1996).

The public sector is comprised, at the broadest level, of public entities and "general government and procures goods and services using public funds (Lienert, 2009). Public enterprises are resident public corporations owned and/or controlled by government units (Lienert, 2009) and governed by the values and principles of effective, efficient, transparent, accountable and coherent government (Schiavo-Campo and McFerson, 2014). Hughes (2012) defines the public sector as engaged in providing services and in some cases goods the scope and activity determined by the decision of government bodies, which means, in a democracy, by the 
representatives of the citizens (Bovis, 2012). As stated public-sector's funding -sources end up in the procurement loop as is drawn from taxes and carry with them innate external regulations regarding their use. Public-sector procurement considers the development of its local economy and small businesses, job creation, fair competition, general services and transparency as paramount (Ghansah, 2016; Dzuke \& Naude, 2015).

Another important area that needed to be forecasted in the sub-field procurement versus public administration is the purpose, function and role of the state. Thornhill, Van Dijk and Ile (2014) identified the state as providing economic and infrastructure development, various collective goods and services. The role of the state is to direct the socio-economic goals through the implementation of procurement policies (Hughes, 2012). The purpose, function and role of the state or public administration or government are noteworthy in public procurement in terms of creating a viable legislative environment that is fit for purpose. Thornhill (2012) defines a state as a demarcated geographical area with a permanent population government by a legitimate governing body. Arrowsmith (2011) defines a state as including all the bodies exercising legislative, executive and judicial powers at the national, federal or local level. Procurement fits into the state's purpose, role and function, especially as it relates to the promotion of socio-economic goals of the state and expenditure management.

The discussion on the state is paramount to show the link which procurement and government. Service delivery by the state through public administration is both a consequence of and integral to the rights of its citizens transcended by its classic concept of a provision or procuring of public goods (; Schiavo-Campo \& McFerson, 2014). Public procurement is an important function of the state and as such, it would be imperative in the administration of procurement practice to ensure that public funds are utilized for the purpose for which the legislature intended. Sobel, et al (2011), state that for centuries, philosophers, economists, and other scholars have debated the proper role of government and procurement administration is not an exception. The state has to provide for public goods such as national defense and government services through procurement. Efficient resource allocation depends on compiling a list or complete description of who does what and who gets what in the economic set-up (Begg, et al, 2011; Taylor and Raga, 2010; Teixeira, 2016). Debatably, goods and services provided through market mechanisms are essential for citizens or consumers at large. To this end, the state has to allocate resources between private goods and public goods.

The common shortfalls in planning and management of procurement in the procurement authorities include needs that are not well estimated, unrealistic budgets or officials who are under-skilled and professional deficiencies in procurement administration (OECD, 2009). Procurement planning and incidental expenditure are important in reflecting the long-term and strategic view of needs in government. The state can fulfill its purpose when the administration of procurement practice is geared towards long-term planning of infrastructure development. McCrudden (2004) asserts that procurement policies are targeted as a vehicle to achieve a range of social objectives. Public procurement allows the government to combine two functions i.e. that of a purchaser and regulator in the market using its purchasing power to achieve social justice.

The regulatory framework within the confines of the administration procurement practices provides impetus within the South African public sector (South Africa, Republic, 2017a; Gildenhuys, 1997). About the regulatory role, the National Treasury plays a leading role in ensuring that the supply chain practices are adhered to and reformulated in the event that they are outdated (World Bank, 2012). A key condition for public procurement system to operate with integrity is the availability and effectiveness of accountability and control mechanisms (OECD, 2009). To this end, governments should appreciate that procurement needs to be integrated into a more strategic view of government activities. The state of affairs is done to improve efficiency in public spending.

Certainly, legal, institutional and political conditions to implement principles are imperative as government needs to ensure that the effort to enhance integrity in public procurement at the policy level should be supported by national leadership and a sufficient public procurement system (OECD, 2009). The macro environments (political, economic, legal, social, technological and international) are critical in public finance and so in public administration and its concomitant subfield procurement. The political environment as it relates to political will in fighting corruption and state capture is fundamental in taking procurement to 
greater heights. The government recognizes procurement infrastructure as one of the pillars that supports a better life for all as it serves social and economic needs (South Africa, Republic: National Treasury, 2015a; 2017a).

Public policy theory is an attempt by a government to address public issues by instituting acts, procedures, resolutions, or activities pertinent to the problem at hand(Lamidi, 2015) for example state capture is fundamental in Public Administration theory. Public procurement is central to the economic activity of a country as procurement is the interaction between private and public sectors and the community at large and without political will nothing will be forthcoming. Van der Walt \& Du Toit (1999) assert that legal issues include factors such as the constitutional system, the nature of the legal system, legislation, and directives concerning the formation and control of instructions within the state. The public procurement framework should promote fair competition and prevent discrimination in public procurement (EBRD, 2010). The matter suggests that policies and regulations should be the order of the day in government. Certainly, there should be clear rules on the choice of methods and ensure sound competitive processes procurement administration

Public procurement has to be viewed as a primary slice of community monetary organization. Arguably, this can assist in stand-in transparency and answerability from disbursement planning to last payment. Government contracts can give rise to mistakes, anomalies, fraud, and misappropriation of public funds or instances of corruption (OECD, 2009). The charter governing public procurement can regulate whether the government is cultivating the method in which public management is controlled. The societal location plays an important role in government activities and administrative processes. The South African government has deemed it fit to ensure that the conditions of the local people are addressed by eradicating the previously discriminatory practices in public procurement (Van Der Waldt \& Du Toit, 1999; Fox., et al, 2004; Begg., et al, 2011; Holzer \& Schwester, 2011; South Africa, Republic, 2016). The administration should deliver prospective suppliers and freelancers with vibrant and unswerving material concerning procurement. Certainly, procedures require understanding and are thus applied equitably. The right of entry to legislation and guidelines, organizational pronouncements and typical agreement phrases on procurement are chief.

\section{Method}

The study is underpinned by the qualitative research method. The data was collected from secondary data in books, reports and journal articles for public administration and public procurement and private procurement books.

\section{Discussion}

The administrative activities (policymaking, financing, organizing, control, personnel provision and utilization, work methods and procedures and management functions) are imperative in that governments and state-owned enterprises procure a variety of goods and public works (OECD, 2009). Certainly, these activities if applied and enforced productively can add value and minimize the cost of procurement in government spending. The cited activities are interconnected and they have to be used collectively to arrive at equilibrium or balance in procurement administration. To this end, public procurement can fit into public administration in terms of the manner in which administrative functions are practiced or enforced in government.

Public administrative functions are an important part that answers two objectives: administration of procurement practices, and framing of a public procurement framework (Marume, 2016). In procurement, the function as an activity of public administration, the policy-making (rules, regulations, policies, legislation, frameworks, guidelines), and the other five activities or functions (financing, organizing, control, personnel provision and utilization, work methods and procedures and management functions are significant in running the procurement organization/authority or unit.

To put this argument in perspective, in running a procurement process one government need policy or legislation, needs finances to hire professionals, need to have and organized a structure, need work methods and procures to guide the government in terms of how things should be proceeded with, you need control 
and oversight bodies so that things do not run haywire, one needs management functions to ensure things are collective business like done in a manageable manner. As such the six administrative functions are chief in procurement activities in administration. Procurement needs management per degree for effective and economically driven public administration is crucial (Holzer \& Schwester, 2011; Denhardt \& Denhardt, 2009). As a management function, public procurement is directed effectively and efficiently towards the allocated resources in public administration.

An institutional system is important for the success of procurement in public administration. To this end, an institutional system that can be fit for purpose in terms of being accountable, transparent, equitable and adding value in the procurement function is fundamental in administration. To make the procurement system work at all levels, a set of functions performed at all spheres of government levels are arranged (Bianchi \& Guidi, 2010). The core financial management function rests with the accounting officer/authority of each organ of state and a procurement unit established which is headed by Chief Procurement Officer (Quinot, 2014; South Africa, Republic, 2017b). National Treasury has general purposes and supremacies of oversight, which apply to public procurement. Monitoring of public coffers and procurement should also be done by sovereign oversight institutions as indicated above. The administration of procurement is supported by various oversight bodies, such as the Auditor-General of South Africa to mention but a few oversight bodies; which are paramount in procurement the administration (South Africa, Republic, 2015b). Oversight bodies are control machinery that is paramount in procurement to assist to eliminate corruption and state capture. All-encompassing reporting is major during the procurement methods. Such is done to support investment outlay resolutions, asset, acquisition and contract management and disbursements.

In Public administration, procurement is structured in terms of processes and performance modeling; and organizational culture must be controlled to limit corruption (Mazibuko, 2018) The efficiency of procurement can be measured in terms of the efficiency of its process, openness and transparency of the professionalism of the procurement workforce and contract management performance (World Bank, 2012). Taylor and Raga (2010) \& Raga (2008) posit that procurement procedures are developed for specific fields of work and often serve as the foundation within the procurement units. Certainly, procurement methods and procedures are at the center of procurement administration.

Professional and qualified staff with the highest integrity and moral standing is key to the implementation of procurement funding and supply chain management (Thornhill, 2012). Officials deployed in procurement administration have to be recognized as working in the professional field of public administration. Highly trained personnel become essential in public administration, and trained and competent persons are required to deal with highly specialized matters of public procurement (Marume, 2016). The staff assigned for the administration of procurement practices are assessed and appraised as prescribed by law. The human resources staff and the individual system as centralized function in public administration and procurement is done to ensure that staff performance is measured against monthly, quarterly and annual performance targets.

\section{Conclusion and Recommendations}

Procurement is relevant and decisive in public administration as it involves the public spending of huge amounts of budget and money. Such budgets are taxpayers' money and have to be spent taking into account the notions of value for money, professional ethics, ethical leadership and conflict of interests.

Standardization and Professionalization of Public administration procurement: - Benchmarking and standardization of public procurement practice in terms of improving bid processes are paramount in public administration. The public administration milieus with regard to the influence, which they may have on procurement regarding procurement need assessment and planning. Principles of Public administration are fundamental in providing founding values and morals in public administration. The procurement is impacted by the political environment and when implemented effectively can enhance the chances of growing the economy of a country. 
Institutional system: - The administration of procurement milieu is paramount in public administration and therefore, an ethical, responsible and accountable system should be the order of the day. The importance of procurement in public administrative functions with regard to controlling to minimize corruption and state capture are key in public administration. The budget needs $\mathrm{w}$ planned should be executed in an effective, efficient and delivered to uplift the conditions of lives of the entire community. Oversight with and accountability in public procurement activities cannot be overemphasized in public administration and as such need to be put as a priority all the way.

Relevance and recognition of public procurement: - Public procurement as a subfield and activity of Public Administration is relevant in public administration. To that end, it is critical that public procurement finds a clear course specifically named public procurement. There are various challenges regarding public procurement practices that warrant a true recognition of public procurement in schools and Universities. Perhaps the issues on corruption are not easily solved due to the neglect in which public procurement awareness experience in both practices and as a theory is conducted.

\section{References}

(EBRD), European Bank for Reconstruction and Development. (2010). Regional Assessment of Public Procurement Legal Framework. Astana (KZ): EBRD.

(OECD), Organization of Economic Cooperation and Development. (2009).OECD Principles for Integrity in Public Procurement. Paris: OECD Publishing.

Arrowsmith, S. (2011). EU public procurement law: An introduction. Public Law Review. London (UK): Sweet and Maxwell.

Arrowsmith, S. and Quinot, G. (2013). Public procurement regulation in Africa. Cambridge (UK): Cambridge University Press.

Aziz, M.A., et al. (2015). Enhancement of the accountability of public sectors through integrity system, internal control system and leadership practices: A review study. 7th International Conference on Financial Criminology (pp. Pages 13-14). Oxford: Wadham College.

Basheka, M. (2012). The paradigm of public administration re-examined: A reflection. Journal of Public Administration, 47, 25-87.

Begg, D., Fischer, S. \& Dornbusch, R. (2011). Economics. 5th Ed. London: McGraw-Hill.

Bianchi, T and Guidi, V. (2010). The comparative survey on the national public procurement systems across the PPN. Authority for the Supervision of Public Contracts/Department for the Coordination of European Union Policies. Rome: EU.

Bovaird, T and Löffler, E. (2010). Public management and governance. 2nd ed. New York (NY): Routledge.

Bovis, C. (2012). EU procurement law. 2nd ed. Cheltenham (UK): Edward Elgar.

Denhardt, R.B, Denhardt, J. V. and Blanc, T. A. (2014). Public administration: An action orientation. 7th ed. Boston (MA): Wadsworth Cengage Learning.

Dobie, K. and Xinwa, N. (2015). Understanding the municipal procurement process: A guide for businesses. Pretoria (ZA): Ethics Institute of South Africa.

Dzuke, A. and Naude, M.J.A. (2015). Procurement challenges in the Zimbabwean public sector: A preliminary study. Journal of Transport and Supply Chain Management. 9 (1), 1-9.

Elkatawneh, H. H. (2013). Classical theories of public administration. Electronic copy available at: http://ssrn.com/abstract.uploaded on 11 March 2019.

Flynn, A and Davis, P. (2014). Theory in public procurement research. Journal of Public Procurement. 14(21), 139-180.

Fourie, D. (2015). Procurement in the South African public service: A reflection of the ethical and legislative framework. Public and Municipal Finance. 4(2), 38-45.

Fourie, D. and Malan, C. (2020). Public Procurement in the South African Economy: Addressing the Systemic Issues. Sustainability2020.12(8692), 1-23.

Fox, W., Schwella, E. and Wissink, H. (2004). Public management. Stellenbosch (ZA): Sun Press.

Garcia, R. (2009). International public procurement: A guide to best practice. London (UK): Globe Law and Business.

Frederickson, H. G., Smith, B. K., Larimer, W. C. \& Licari, J. M. (2012). The Public Administration Theory Primer. $2^{\text {nd }}$ Edition. Philadelphia: Westview Press. 
Ghansah, E. (2016). Enhancing public procurement practices in Ghana. Dama International Journal of Researchers (DIJR). (5), 8-11.

Gildenhuys, J. (1997). Public financial management. . Cape Town (ZA): JL van Schaik Publishers.

Henry, N. (2013). Public administration and public affairs. 12th ed. Boston (MA): Pearson.

Holzer, M and Schwester, R.W. (2011). Public administration: An introduction. New York (NY): M.E. Sharpe.

Hughes, O. (2012). Public management and administration: An introduction. 4th ed. New York (NY): Palgrave Macmillan.

Ijeoma, E.0.C. (2013). South Africa's public administration in context. 1st ed. Pretoria (ZA): Verity Publishers.

Krivinsh, A. and Vilks, A. (2013). Prevention of corruption in public procurement: Importance of general legal principles. Jurisprudence, 20 (1), 235-247.

Lienert, I. (2009). Where Does the Public Sector End and the Private Sector Begin? WP/09/122. IMF Working Paper. New York (NY): International Monitory Fund (IMF).

Marume, S. (2016). Generic review of public administration. Journal of Research in Humanities and Social Science, 4 (6), 15-20.

Mazibuko, G. and Fourie, D.J. (2017). Manifestation of Unethical Procurement Practices in the South African Public Sector. African Journal of Public Affairs, 9(9), 106-117.

Mazibuko, G. and Fourie, D.J. (2013). Municipal Finance: Relevance for Clean Audit Outcomes. Administratio Pública, 21(4), 130-152.

Mazibuko, G.P. (2018). (Unpublished). Analysis of the Administration of Procurement Practices in the South African Public Sector. Doctor of Administration in Public Administration (Ph.D.). Pretoria: University of Pretoria.

McCrudden, C. (2004). Using public procurement to achieve social outcomes. Natural Resources Forum. 28 (4), 257-267.

Lamidi, K.O. (2015). Theories of public administration: an anthology of essays. International Journal of Politics and Good Governance, I (6.3). Quarter III 2015.

Quinot, G. (2014). An institutional legal structure for regulating public procurement in South Africa: Research report on the feasibility of specific legislation for National Treasury's newly established office of the Chief Procurement Officer. Final Report. Pretoria (ZA): National treasury.

Raadschelders, J. (2011). Public Administration: The Interdisciplinary Study of Government. New York: Oxford University Press.

Raga, K. (2008). Public sector procurement: South African ethical and legislative aspects. African Journal of Public Affairs, 2(1), 109-121.

Rutgers, M. (2010). Foundations of public administration: Theory and scope. Public Administration Review, 145)

Schapper, P. (2008). The impact of e-procurement on corruption: The potential of e-procurement for curbing corruption risks. In: ADB/OECD. 2008. Fighting bribery in public procurement in Asia and the Pacific. The 7th Regional Seminar on Making International Anti-Corruption Standards Operational, Indonesia 2007.

Schiavo-Campo, S and McFerson, H.M. (2008. Public management in global perspective). Public management in global perspective. New York: M.E. Sharpe, Inc.

Schumpeter, E. (1954. History of economic analysis). History of economic analysis. London (UK): George Allen and Unwin Ltd.

Shafritz, J.M. (ed). (2000). Defining public administration. Selection from the international encyclopedia of public policy and administration. Boulder (CO): Westview Press.

Sobel, R.S., et al. (2011). Understanding macroeconomics. Melbourne (AU): South-Western/Cengage Learning.

South Africa, Republic (RSA). 1996. Constitution of the Republic of South Africa, 1996. Pretoria (ZA): Government Printer

South Africa, Republic (RSA). 2015a. Construction Industry Development Board (CIDB). Standard for uniformity in construction procurement. Pretoria (ZA): Government Printer.

South Africa, Republic (RSA). 2015b. 2015 Public sector supply chain management review. Pretoria (ZA): National Treasury.

South Africa, Republic (RSA). 2016. SCM review updates 2016. Pretoria (ZA): National Treasury.

South Africa, Republic (RSA). 2017a. Capital planning guidelines. Pretoria (ZA): National Treasury.

South Africa, Republic (RSA). 2017b. Preferential procurement regulations. Pretoria (ZA): Government Printer. 


\section{Journal of Social and Development Sciences (ISSN 2221-1152)}

Vol. 11, No. 4, pp. 26-34, December 2020

Taylor, J.D. and Raga, K. (2010). Preferential procurement: A case study of South Africa. Working Paper 13-6. Available from: http://www.ippa.org/IPPC4/Proceedings/13ProcurementPreferences/Paper136.pdf. (Accessed 20 October 2017).

Teixeira, D.P.R. (2016). The differential public procurement regime ('RDC') for the 2014 Brazil FIFA World Cup and the 2016 Rio Olympics. http://www.ippa.org/IPPC5/Proceedings/Part3/PAPER3-6.pdf. (Accessed 3 October 2017).

Thornhill, C. (2012). JJN Cloete's South African public administration and management. 10th ed. Pretoria (ZA): Van Schaik Publishers.

Thornhill, C. and Van Dijk, H.G. (2010). Public administration theory: Justification for conceptualization. Journal of Public Administration. 45(1.1), 95-110.

Thornhill, C., Van Dijk, G. and Ile, I. (eds). (2015). Public administration and management in South Africa: A developmental perspective. Cape Town (ZA): Oxford University Press.

Trevino, L.K. and Brown, M. E. (2006). Managing to be ethical: Debunking five business ethics myths. Strategic Human Resource Management: Theory and Practice. 18(2), 69-81.

Turley, L. and Perera, O. (2014). Implementing sustainable public procurement in South Africa: Where to start. Pretoria (ZA): IISD Report.

Uromi, S. (2014). Challenges facing public procurement information in some African countries, namely South Africa, Uganda, Zimbabwe and Tanzania. International Journal for Innovation Education and Research. 2(7), 54-60.

Van Der Waldt, G. and Du Toit, D.F.P. (1999). Managing for excellence in the public sector. 2nd ed. Kenwyn (ZA): Juta \& Co. Ltd.

World Bank. (2012). Why Reform Public Procurement? Washington DC: World Bank.

World Trade Organisation (WTO). (2012). Revised Agreement on Government Procurement and WTO-related legal instruments. Geneva (CH): World Trade Organisation (WTO).

World Trade Organisation (WTO). (2011). UNCITRAL: Model law on public procurement. Geneva (CH): World Trade Organisation (WTO). 